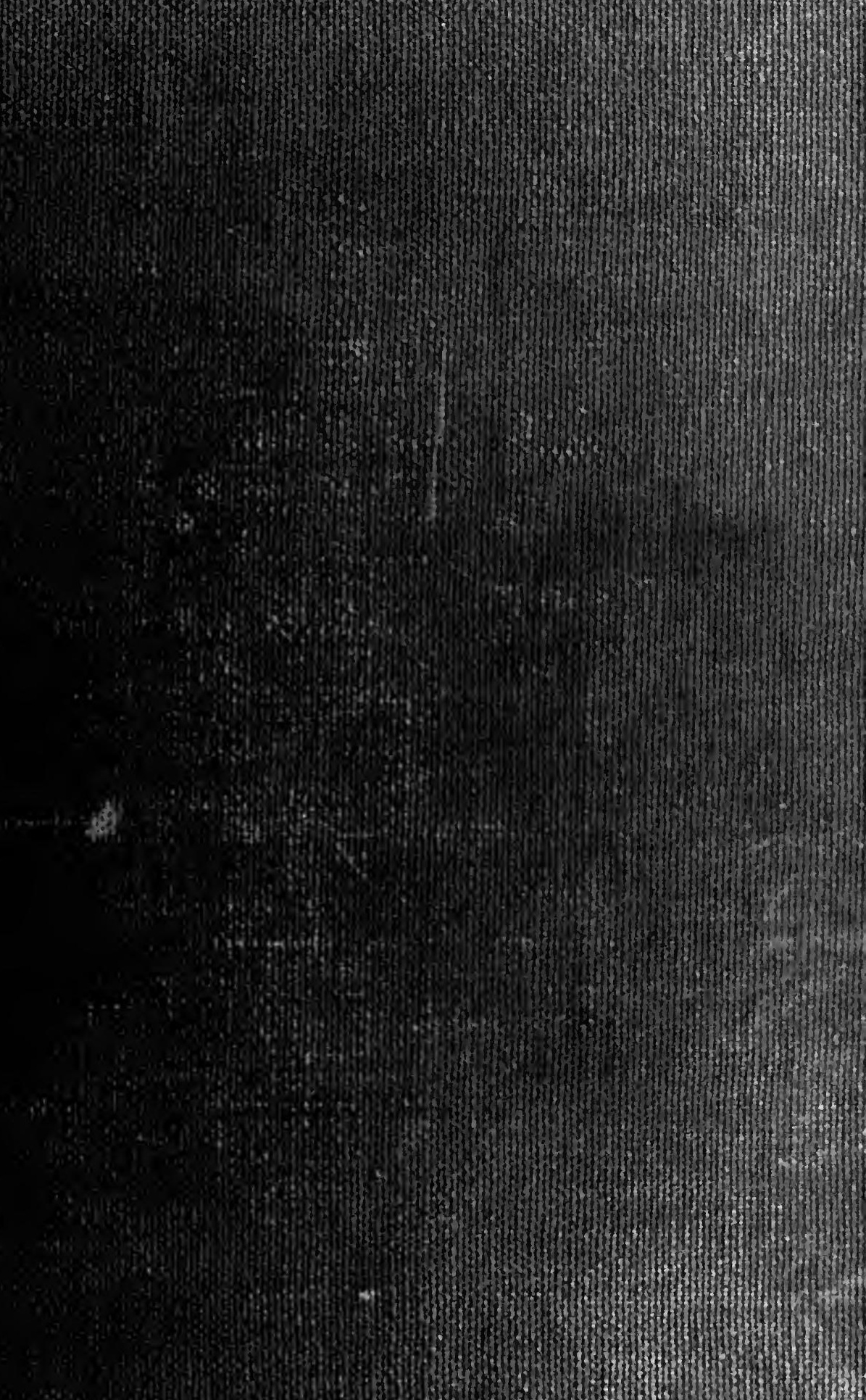




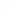




\section{PUBLICATIONS}

OF THE

\section{Clark UNIVERSITY LIBRARY}

WORCESTER, MASS.

Epited ax Louis N. Wilgon, Litr. D., Lrmarian

Vol. 5

April, 1917

No. 4

\section{POSTERS AND PICTURES}

Relating to the

\section{EUROPEAN WAR}

By

LOUIS N. WILSON, Librarian

Clark University 


\section{Digitized by the Internet Archive in 2007 with funding from Microsoft Corporation}




\title{
POSTERS AND PICTURES RELATING TO THE EUROPEAN WAR
}

\author{
By Louis N. WiLson, Librarian, Clark University
}

In August 1914 immediately after the breaking out of hostilities Clark University Library decided to make as complete a collection as possible of the printed material dealing with the great conflict, and we at once instructed our booksellers to send us, for inspection, any and all books and pamphlets relating to the war, as soon as they were published. I also wrote to personal friends in Russia asking them to send us any items of interest that appeared in that country on the same subject. Toward the end of 1914 we received from Mr. and Mrs. Frederick M. Corse of Petrograd a few of the first Russian war cartoons. They were not particularly artistic but they were most interesting and attracted a great deal of attention as coming from Russia and as the first of the war posters to be seen here. Then followed the exhibition of English recruiting posters by Mrs. Fiske Warren in Boston; of these we purchased as many as we could and thus we were committed to collecting posters and pictures as a part of our war collection.

In December $1916 \mathrm{Mr}$. Louis Raemaekers consented to design a special book plate for this collection, the receipt of which we are now impatiently awaiting.

Of books and pamphlets dealing with the war we have received over 3,600. A few of the German books Dr. Lyon reviewed in the April 1917 issue of the Journal of Race Development (vol. 7, pp. 385-409) and the members of the Seminary in History have reviewed some of the English and American' books for the July issue of the same Journal. Since March 1916 we have received practically no German material, but we have every reason to suppose that some 2,000 or 3,000 items are awaiting the day when the war shall end and they 
may be shipped to us. But the literature of the war is not our present task, so let us turn to our subject.

In addition to 2,000 of the official French photographs our collection now numbers 1,060 Posters and Pictures, divided by countries as follows:

England

France

Germany

Russia

Holland

117
437
160
132
143

Italy

Japan

Australia

Canada

$\begin{array}{r}19 \\ 13 \\ 7 \\ 32 \\ \hline 1060\end{array}$

These are all single pictures or sheets that have been mounted on cotton cloth to ensure preservation, and does not include a large number of bound volumes of Gift Books, cartoons and illustrations dealing with the war, of which we already have over one hundred and fifty.

ENGLAND. The first posters were issued in England for recruiting purposes. England was the only nation in Europe at the time the war broke out that did not have a system of compulsory military service. With a standing army of only 200,000 soldiers she was ill prepared to enter the great conflict on land and would have fallen an easy prey had it not been for her sea strength-if, indeed, she could have entered the war at all.

Faced, then, with the necessity of raising troops and faced also with the Englishman's aversion to compulsory service, and a large standing army-an aversion dating from the days of the Stuarts-there was but one thing she could do, appeal to the patriotism of her people and induce her sons to enlist for the war. A national recruiting committee was formed and under its auspices over three million men were added to her fighting forces in the course of two years. Now that we face a somewhat similar problem we are told that England made a great mistake in not adopting conscription in August 1914, as she finally did in 1916, but it is very doubtful if a conscription bill could have passed the House of Commons in August 1914. At that date the English were not "keen" for war and their own grave danger was not apparent to them. Even two years later there were many who dreaded and fought the passage of a conscriptive measure. 
One of the first evidences of the work of the Parliamentary Recruiting Committee was the appearance throughout Great Britain of the recruiting posters, ranging in size from, roughly, $58 \times 39$ in. to $30 \times 19$ in. The committee evidently had the assistance of experts in this field as the posters themselves, and the results they achieved, amply testify. The pictures are simple and avoid detail. A single figure of a man in uniform beckoning, and not a word of print on the sheet; a soldier with gun and bayonet, a black figure silhouetted against a yellow background and only the words "Be Ready. Join Now." A map showing the southern coast of England and the northern coast of France on which stands an English soldier in khaki shading his eyes and looking toward England, with the words "Boys, Come Over Here You're Wanted." The figures of two English soldiers on the crest of a hill with fixed bayonets, silhouetted against a rosy sky, and the words “Don't Stand Looking At This. Go and Help!" These are, perhaps, among the best of about 150 that appeared. Historical figures are almost entirely absent. There is one that bears the face of Earl Kitchener and his appeal for volunteers; another with battle ships and the figure of Lord Nelson, with the words 1805 "England Expects" 1915 "Are you doing your duty To-Day." One showing the map of the British Isles and the face of King George.

Almost all are pictorial, the notable exception being the largest sheet of all, measuring 78 x 58 in., headed " Remember the Lusitania" and, after recounting the verdict of the coroner's jury, "It is Your Duty to Take up the Sword of Justice to Avenge This Devil's Work. Enlist To-Day."

Later on when the War Loans were put out, about 25 posters were issued by the Parliamentary War Savings Committee and these again proved very effective. They are about all of the smaller size, $30 \times 19$ in., and are not so interesting, pictorially, as the recruiting posters.

Taking these English posters as a whole one notices three things; artistic merit, simplicity, and size. The aim is to attract attention and to hold it. In this respect the larger ones seem to have been most effective.

Other posters were issued, some being reproductions from 
Punch, and some drawn by Spencer-Pryse and by Frank Brangwyn, these latter often commanding high prices as works of art. One of Brangwyn's figures "The Prisoner" shows a face peering in at the grating of a cell where a soldier is seated, with head buried in his arms on a table. The whole attitude of the figure is indicative of despair and it is a striking bit of great artistic merit. Many of these pictures now sell at from five to ten dollars each, while his "Violation of Belgium" has brought as much as twenty-five dollars.

Of paintings of the war scenes we have none except reproductions of three charming water colors by E. HandleyRead of the Machine Gun Corps.

FRANCE. Although the French needed no recruiting posters they have probably issued more posters and pictures than any other nation. These posters differ from the English in that they are all issued for the purpose of raising money for charitable purposes; for hospitals; for orphans; for the families of those at the Iront; for those crippled in the war, and for special collections for the Serbs or the Belgians. The pictorial element is not so prominent a feature as in the English recruiting poster and there is more printed matter, but they have the charm that attaches to almost every thing done by this wonderful nation. So far as we have seen there is no duplication between these and the English except in one case. A French War Loan poster has the figure of a German soldier overborne by a French gold piece on which the Gallic Cock is shown with open beak outstretched; the lettering is " Pour la France. Versez Votre Or. L'Or Combat Pour la Victoire." While one of the English shows a prostrate German soldier under a five shilling piece with the words, "Send Your Five Shillings To Your Country and Crush the Germans."

Pictures dealing with the war France has issued in great quantity, many being the work of well known artists like Steinlen and Lucien Jonas. There are also innumerable sets of a less pretentious kind by such men as Geoffroy, Guy Arnoux, J. G. Domergue, J. Bac, and others.

Some of these pictures are very impressive, as the one 
showing the German Kaiser stooping over to examine a fallen crucifix and asking "Est-il cuivre?" Another shows a bed room with a bed, a bureau, beside which stand two little girls, one holding a doll in her arms while a boy crouches at the foot of the bed gazing at an open window through which is seen a German helmet and a much beringed hand on the window stool. The little lad says, "Le v'la! Vite, cache ta poupée, Simone!"

Lucien Jonas is perhaps the best represented in this French group. His pictures are excellent and many of them have a religious cast. One shows the interior of a Church; before the altar lies a dead priest, while on one side stands a German soldier drinking from the sacred vessel, and another sits on the altar steps singing or reading from a book. He has a number of spirited drawings of trench attacks; one "Before Verdun" shows French soldiers firing over the walls and the German dead lying thick in front. One other deserves mention-that of a blind soldier being led by a Red Cross Sister. The pathetic figure of the man with his cane in one hand, feeling his way, while the outstretched fingers of the other hand, the head thrown back, and the pitying expression on the face of the Sister, all combine to make a powerful picture.

Of Proclamations by the government and by the City of Paris there are seventy. These cover; Message Du President de la Republique Française a la Nation Française (29 juillet 1914) commençant par ces mots “Depuis quelques jours l'etat de l'Europe." Signé Poincare.

Message du Président de la République au Sénat et à la Chambre des Deputés, le 4 août 1914. Déclaration de guerre.

Déclaration du Gouvernement lue le 4 août 1914, par M. Réné Viviani, a la Chambre des Deputés et au Sénat. Déclaration de guerre.

Discours de M. A. Dubost, président du Sénat, le 5 août 1915.

Message du Président de la République, le 5 août 1915. Signée R. Poincaré. Cette affiche commence par ces mots: "Dans l'égarement de son orgueil, l' Allemagne s'est répresentée la France légère, impressionnable, mobile, incapable." Notices of the Daylight Saving change of time; rules and 
regulations covering the sale of food, alcoholic beverages, coal, petrol and gasoline, the conduct of the French toward the British troops in their midst, etc., etc.

The 2,000 official war photographs are $41 / 2 \times 6$ in. mounted on mats $10 \times 12 \mathrm{in}$. They show transportation of food and munitions; munition making; Red Cross sections and ambulances; ruins of churches and houses; etc. Many of these are quite familiar as they have been reproduced in the illustrated papers and magazines.

GERMANY. Immediately after war broke out there came from Austria excellent pictures of the higher officers of the Austrian and German army and navy. (Unsere Heerführer. Maler, Oskar, Brüch. K. u. K. Kriegsministerium, Kriegs Fürsorgeant, Wien. IX.) They are in tint and each one bears the man's signature in fac-simile underneath. They measure $11 \times 15 \mathrm{in}$., and there are here 120 of them. They are a fine looking set on the whole, even to the strong, massive jowl of Von Hindenberg.

From Teubner of Leipzig came a set of twelve plates in black and white. (Führer und Helden. Federzeichnungen von Karl Bauer, 1914). Another set of fourteen with a foreword by Dr. Karl Lamprecht. (Unsere Führer im Weltkrieg, 1914. Springer, Leipzig. Oct. 1914.)

Later on came a portfolio containing ten views of the devastation caused by the Russians in East Prussia, with an introduction by Edgar Alfred Regener. (Bilder aus Ostpreussens Not. Von Bruno Bielefeldt. Bei Georg D. W. Callwey, Munchen.) Showing ruined homes and desolation. Will they ever give to the world pictures of the desolation they have caused in Belgium, France, Serbia, and Roumania?

Another set is "Aus Galizien und Polen" 14 Steinzeichnungen vom östlichen Kriegsschauplatz, von Max Buchever. E. Reinhardt, München. There is another series; (1914-1915 Ein Mappenwerk mit 30 Bildern von Fritz Erler u. Ferdinand Spiegel. O. Troitzsch, Berlin) of which only the first picture has been received. It is $17 \times 20$ in., in tint, and shows the German trenches with bombs bursting near by.

Perhaps one of the most characteristic sets, however, is 
"Zwolf Kriegsbilder" Von B. Wennerberg. A. Langen, München, a series of beautifully drawn and colored pictures showing life in the Fatherland during war time. There are a dozen of them-a wounded officer recounting his exploits to two young ladies; gay crowds about bulletin boards announcing German victories; an officer on furlough being taken out in a boat by two fair ladies; a soldier in a restaurant surrounded by a group of waitresses all smiling upon him while a civilian at a near by table receives no attention; a group of pretty girls gathered about a table following the movements of the army on a map; a sentinel in the street whose helmet is decorated with flowers by two girls; a train all decorated with boughs and loaded with soldiers who are being served with coffee and roses by a group of girls; etc., etc. Not a sad note any where; all joyousness, gay colors, pretty girls and smiling faces. One wonders if this is true today.

Unfortunately the German collection is small at present and we must wait until the war is over to get a correct idea of her point of view as shown in pictures.

RUSSIA. During her earlier wars there were issued in Russia a large number of cheap gaudy prints of battle scenes with a short description of each underneath. These pictures sold for about two cents apiece and were very popular throughout the Empire. In the early months of this war a similar crop appeared. They represent gallant acts of Russian troops; bombs bursting in livid flames and blood flowing in rivulets. Similar pictures have been issued by the Italians and the Japanese. Later came another series of a little higher typea cossack driving a Turk out of Constantinople; a Russian soldier seated on a drum smoking a cigarette and smiling at a Turk who storms and rages in front of him while in the background are the towers and minarets of Constantinople; a soldier dragging by the ear a German in one hand and an Austrian in the other; a peasant of huge bulk playing ninepins with the Teutonic cities, probably intended to represent the great power of the Russian Empire.

In November 1916 our good friends the Corses of Petrograd sent us fifteen of the new Russian war loan cartoons which 
had just appeared there. They were a distinct improvement upon previous Russian posters we had received and showed unmistakable signs of having been modeled after the English and French posters, although in no sense copies:-A soldier with fixed bayonet standing between the walls of a trench; outlines of the figures of soldiers in white lines against a red background; soldiers wrapped in furs on guard with snow covered landscape; machine gun corps at work; sailors loading naval guns, with a Russian navy flag underneath; the Russian double headed eagle driving the German eagle to earth; an aeroplane with mounted gun; a mediaeval horseman in gorgeous trappings carrying the imperial standard-and various pictures of munition works and munition trains, go to make up a very fascinating collection, small as it is.

HOLLAND. With one exception the only Dutch pictures in this collection are those of Louis Raemaekers, perhaps the most important artist figure brought out by the war.

Louis Raemackers was born April 6, 1869 at Roermond. His father Josephus Raemaekers was an editor and publisher with an artistic bent as is shown by the great interest he took in bringing about the restoration of the beautiful Church of Our Beloved Lady at Roermond in Limburg where the family lived. His mother was of German birth and is still alive and very much in sympathy with the work her son is doing for the allies. When the war broke out Raemaekers was living quietly in the historic town of Haarlem where he was known as a clever landscape artist and portrait painter. $\mathrm{He}$ has a wife and three children, two girls and a boy.

The first cartoons appeared in the Amstcrdam Telegraaf and immediately commanded world wide attention. They have been reproduced in millions of copies and have penetrated to every corner of the civilized world. The first pictures were not directed primarily against Germany, but against the horrors and cruelty of war in general. But the treatment of the Belgians by German soldiers aroused Raemaekers's chivalrous spirit and from that time his pictures have created perhaps more rage and indignation in Germany than any other single factor in the war. 
It is stated that the German frontier guards offered the Dutch soldiers 12,000 marks if they would hand Raemaekers across the border. Whether this is true or not we cannot say, but the Cologne Gazette, in a leading article on Holland, threatened that country that "after the war Germany will settle accounts with Holland, and for each calumny, for each cartoon of Raemaekers, she will demand payment with the interest that is due to her." It is certain that strong protests were made by the German Government which represented that such work seriously jeopardized the neutrality of Holland. Raemackers was arrested on this charge and it is needless to say he was discharged. He found it convenient to leave Holland for England where he was received by the Prime Minister, and was entertained and feted wherever he went. $\mathrm{He}$ has received the Cross of the Legion of Honour at a special reception held in his honor at the Sorbonne in Paris.

This collection contains Raemaekers' pictures in four sets: (1) Seven parts issued by the Uitgevers-Maatschapp. "Elsevier." Amsterdam, each containing twelve cartoons; (2) The "Land \& Water." edition issued in shilling numbers to be completed in twenty-six parts, each part contains twelve cartoons in colors and facing each picture is a page of text contributed by eminent English and French writers; (3) "The Great War." A Neutral's Indictment. One hundred cartoons by Louis Raemaekers. With an appreciation by H. Perry Robinson and Descriptive notes by E. Garnett, London. The Fine Art Society, Ltd. 1916; (4) One hundred and forty-two colored pictures $11 \times 15$ in., mounted on cardboard $15 \times 22$ in.

The originals have brought high prices for war charities and are owned largely by wealthy collectors and Art Museums.

ITALY. The Italian posters are here few in number and mostly of the highly colored type. They are evidently printed in New York and may not represent Italy's poster contribution in this war at all.

JAPAN. The Japanese pictures are also of the highly colored, inexpensive kind, issued as "Illustrations of the Great European War." Each one has a number. The high- 


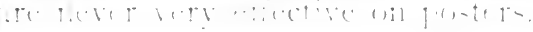

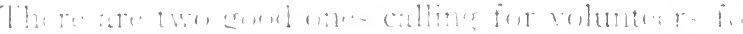

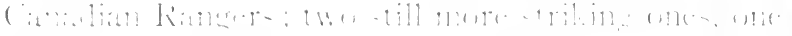

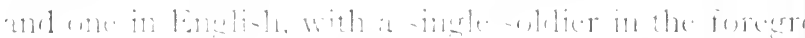

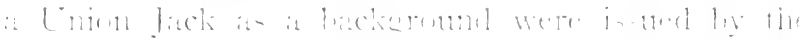

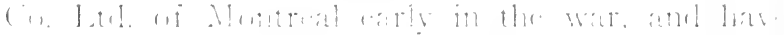

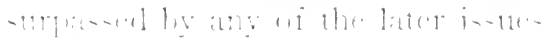

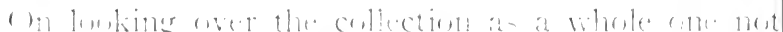

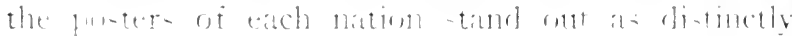


from the rest, except in the case of the crude, highly colored sheets issued in Italy, Japan and Russia, to which reference has already been made.

Some think the poster the best form of advertising and hold that the billboard, suitably located and controlled, might be raised to the dignity of a civic and national asset. Be this as it may, such a collection as is here gathered together is well worth careful study. 

. 
